\title{
The Nature and Enforcement of Choice of Law Agreements
}

\section{Mukarrum Ahmed*}

\begin{abstract}
:
This article seeks to examine the fundamental juridical nature, classification and enforcement of choice of law agreements in international commercial contracts. At the outset, it will be observed that the predominance of jurisdictional disputes in international civil and commercial litigation has displaced choice of law issues to the periphery. The inherent dialectic between the substantive law paradigm and the internationalist paradigm of party autonomy will be harnessed to provide us with the necessary analytical framework to examine the various conceptions of such agreements and aid us in determining the most appropriate classification of a choice of law agreement. A more integrated and sophisticated understanding of the emerging transnationalist paradigm of party autonomy will guide us towards a conception of choice of law agreements as contracts, albeit contracts that do not give rise to promises inter partes. This coherent understanding of both the law of contract and choice of law has significant ramifications for the enforcement of choice of law agreements.
\end{abstract}

Keywords: Choice of law agreement, choice of law clause, classification, promissory, declaratory, enforcement, breach, anti-suit injunction, damages, Rome I Regulation, Brussels la Regulation, mutual trust, effet utile.

\footnotetext{
* PhD (Aberdeen), Barrister (Lincoln's Inn) and Lecturer in Business Law at Lancaster University. This is a companion article on choice of law agreements to the author's recent book titled The Nature and Enforcement of Choice of Court Agreements: A Comparative Study (Hart Publishing, 2017).
} 


\section{Introduction}

This article examines the fundamental juridical nature, classification and enforcement of choice of law agreements in international commercial contracts. At the outset, it will be observed that the predominance of jurisdictional disputes in international civil and commercial litigation has displaced choice of law issues to the periphery. The inherent dialectic between the substantive law paradigm and the internationalist paradigm of party autonomy will be harnessed to provide us with the necessary analytical framework to examine the various conceptions of such agreements and aid us in determining the most appropriate classification of a choice of law agreement. In binary terms, we are offered a choice between choice of law agreements as mere "factual" agreements on the one hand or as promises on the other. However, a more integrated and sophisticated understanding of the emerging transnationalist paradigm of party autonomy will guide us towards a conception of choice of law agreements as contracts, albeit contracts that do not give rise to promises inter partes. This coherent understanding of both the law of contract and choice of law has significant ramifications for the enforcement of choice of law agreements. It will be argued that the agreement of the parties on choice of law will be successful in contracting out of the default choice of law norms of the forum and selecting the applicable law but cannot be enforced by an action for "breach" of contract.

The article will commence by assessing the relative significance of choice of law issues as compared to jurisdictional matters in private international law. This will be followed by an examination of the fundamental juridical nature and classification of choice of law agreements, which is the central concern of this article. Our understanding of the nature of choice of law agreements will then have important implications for the enforcement such agreements.

\section{$\underline{\text { The Primacy of Jurisdictional Disputes in Private International Law }}{ }^{1}$}

Before examining the fundamental juridical nature, classification and enforcement of choice of law agreements, it is useful to digress and assess the broader question of the proper role and scope of choice of law considerations in international civil and commercial litigation before the English courts. ${ }^{2}$ In recent times, it has become apparent in the leading global

\footnotetext{
${ }^{1}$ AS Bell, Forum Shopping and Venue in Transnational Litigation (Oxford University Press, 2003) 14-19, 23-48; R Fentiman, International Commercial Litigation (Oxford University Press, $2^{\text {nd }}$ edn, 2015) 9-12; A Briggs, Agreements on Jurisdiction and Choice of Law (Oxford University Press, 2008) Preface, vii; RH Graveson, Comparative Conflict of Laws (North Holland, Amsterdam, 1977) 8; A Fiorini, "The Codification of Private International Law in Europe - Could the Community Learn from the Experience of Mixed Jurisdictions" (2008) 23 Tulane European and Civil Law Forum 89, 100.

2 See MP Fons, "Commercial Choice of Law in Context: Looking Beyond Rome" (2015) 78 Modern Law Review 241.
} 
centres of transnational litigation that the outcome of a case depends much more on jurisdictional concerns than choice of law.

The significance and frequency of jurisdictional disputes is witnessed by the fact that in the English courts there are far more reported cases on international jurisdiction and procedure than on choice of law. ${ }^{3}$ These jurisdictional disputes are very rarely pursued until trial and are more in the nature of interim border skirmishes between the litigating parties to establish superiority. ${ }^{4}$ This "litigation about where to litigate" ${ }^{5}$ often witnesses a relatively disadvantaged party capitulating and seeking to settle or compromise. However, there may be instances where a coordinated attempt at multistate litigation becomes necessary as in international fraud litigation where the widespread nature of the fraud and its perpetrators, and the dissipation of its monetary proceeds leave no other option. ${ }^{6}$ Therefore, jurisdictional disputes in the English courts may settle before the trial stage where the application of choice of law rules and foreign law become most relevant. ${ }^{7}$

However, from the perspective of transaction planning and litigation strategy, choice of law considerations cannot be ignored as they may determine where a party may sue if the choice of law rules of that forum give a wide effect to the choice of law agreement in the absence of any countervailing factors such as overriding mandatory rules and the public policy of the forum. On the other hand, a party seeking to avoid the choice of law agreement may seek a forum which limits the autonomy of the parties as to choice of law, restricts the scope of the applicable law or contains an anomalous public policy provision, which overrides the applicable law. The applicable law may in some cases determine the outcome of a dispute and thus influence the choice of forum. The applicable law is a factor to consider in determining the natural forum for the purposes of the doctrine of forum non conveniens. ${ }^{8}$ An English choice of law agreement also provides a jurisdictional gateway for service out of the jurisdiction with the permission of the English court. ${ }^{9}$

\footnotetext{
${ }^{3}$ TC Hartley, International Commercial Litigation (Cambridge University Press, $2^{\text {nd }}$ edn, 2015) 6.

${ }^{4}$ C McLachlan, Lis Pendens in International Litigation (Martinus Nijhoff Publishers, 2009) 36-40.

${ }^{5}$ Research in Motion UK Ltd v Visto Corp [2008] EWCA Civ 153, [2008] Bus LR D141, [3] (in the context of the Brussels I Regulation): "Too often one finds parties litigating as much about where and when disputes should be heard and decided as about the real underlying dispute"; See TM Yeo, "The Future of Private International Law in Singapore" Seventh Yong Pung How Professorship of Law Lecture, Singapore Management University (22 May 2014), 17.

${ }^{6}$ McLachlan (supra n 4).

${ }^{7}$ Cf Article 25(1) of Brussels la and Article 5(1) of the Hague Choice of Court Convention provide that the substantive validity of a choice of court agreement will be determined by the law of the chosen forum including its private international law rules. Therefore, a choice of law provision may be applied at the jurisdictional stage to determine whether the choice of court agreement is valid. However, it is likely that the new choice of law rule will be narrowly construed by the CJEU, see Case C-222/15 Hoszig kft v Alstom Power Thermal Services ECLI:EU:C:2016:224, [47], where AG Szpunar examined the scope of the lex fori prorogatum rule and suggested that the new formulation does not attempt to reverse the CJEU 's jurisprudence on the autonomous determination of factual consent.

${ }^{8}$ Spiliada Maritime Corporation v Cansulex Ltd [1987] 1 AC 460, 478 (HL) (Lord Goff of Chieveley); RA Brand and SR Jablonski, Forum Non Conveniens: History, Global Practice, and Future Under the Hague Convention on Choice of Court Agreements (Oxford University Press, 2007) 33; R Fentiman, "Foreign Law and the Forum
} 
The choice of a particular forum in an exclusive choice of court agreement may indicate that the parties intend the contract to be governed by the law of the chosen forum. ${ }^{10}$ At common law, an exclusive choice of court clause is considered to be "a weighty indication"11 of the parties' common intention, albeit "one which may yield to others". ${ }^{12}$ On the other hand, Recital 12 of the Rome I Regulation is more restrictive and provides that an exclusive choice of court agreement should be one of the factors to be taken into account in determining whether a choice of law has been clearly demonstrated. ${ }^{13}$ Unlike the Rome I Regulation which refers to the effect of a forum clause in a recital, Article 4 of the Hague Principles on Choice of Law in International Commercial Contracts contains a direct reference as to the effect of a forum clause on tacit choice of law: "An agreement between the parties to confer jurisdiction on a court or an arbitral tribunal to determine disputes under the contract is not in itself equivalent to a choice of law."14

There are various reasons why choice of law has such a limited influence on the outcome of international civil and commercial litigation. Significantly, the procedural law of the forum is immune from the effects of choice of law. ${ }^{15}$ Moreover, the English common law's rightremedy approach to the substance-procedure distinction adopts a wide view of the proper and legitimate scope of the law of procedure. ${ }^{16}$ However, the EU instruments on choice of law in contractual and non-contractual matters have reduced the scope of the law of the forum, as compared to English common law private international law. ${ }^{17}$

Conveniens" in JAR Nafziger and S Symeonides (eds), Law and Justice in a Multistate World: Essays in Honor of Arthur T. von Mehren (Transnational Publishers, 2002) 275; M Hook, "The Choice of Law Agreement as a Reason for Exercising Jurisdiction" (2014) 63 International and Comparative Law Quarterly 963, 965.

${ }^{9}$ CPR PD 6B para 3.1(6)(c).

${ }^{10}$ For a discussion of the English common law presumption Qui elegit judicem elegit jus see, BA Marshall, "Reconsidering the Proper Law of the Contract" (2012) 13 Melbourne Journal of International Law 1, 15-17.

${ }^{11}$ Compagnie d'Armement Maritime SA v Compagnie Tunisienne de Navigation SA [1971] AC 572, 587-91, 593, 596-600, 604-7 (HL); John Kaldor Fabricmaker Pty Ltd v Mitchell-Cotts Freight (Australia) Pty Ltd (1989) 18 NSWLR 172, 187.

${ }^{12}$ Compagnie d'Armement Maritime SA v Compagnie Tunisienne de Navigation SA [1971] AC 572, 596 (Lord Wilberforce).

${ }^{13}$ Regulation (EC) No 593/2008 of the European Parliament and of the Council of 17 June 2008 on the law applicable to contractual obligations OJ L/2008/177/6. ("Rome I Regulation")

${ }^{14}$ Article 4 of the Hague Choice of Law Principles and Commentary in Permanent Bureau of the Conference, The Hague Principles on Choice of Law in International Commercial Contracts (Approved on 19 March 2015), http://www.hcch.net/upload/conventions/txt40en.pdf accessed 24 November 2017.

${ }^{15}$ Lex fori regit processum: "the law of the forum governs procedure": See infra $\mathrm{n} 124$.

${ }^{16} \mathrm{R}$ Garnett, Substance and Procedure in Private International Law (Oxford University Press, 2012) 7-10; Harding $v$ Wealands [2006] UKHL 32, [2007] 2 AC 1; See M Bogdan, Private International Law as Component of the Law of the Forum (Martinus Nijhoff Publishers, 2012) Chapter VIII, 193.

${ }^{17}$ The Rome I and II Regulations adopt a direct approach, whereby certain issues are subjected to the applicable law of the obligation [for example the existence, nature and assessment of damage, (Article 15(c) Rome II; Article 12(1)(c) Rome I) and limitation of actions (Article 15(h) Rome II; Article 12(1)(d) Rome I] and others, for example formal validity, to the law of the obligation or the law of the country of performance of the act (lex loci actus).(Article 21 Rome II; Article 11(1) Rome I) See Garnett, Substance and Procedure in Private International Law (supra n 16) 37-39. 
The English common law's treatment of foreign law may be pragmatic and cost efficient but it lacks a conception of foreign law that is principled, multilateral and does not discriminate on the basis of the origin of the law. ${ }^{18}$ Foreign law is a question of fact for the English courts. ${ }^{19}$ As a consequence, the foreign law has to be pleaded by the party seeking to rely on the law. Furthermore, the content of the foreign law has to be proved to the satisfaction of the court. If neither party pleads the applicability of foreign law, the court will apply English domestic law to the issues in dispute. The English court has neither power nor duty to apply foreign law ex officio. It may be observed that, contract and tort cases litigated in the English courts will frequently be decided by application of English domestic law, even though choice of law rules might have indicated that a foreign law should be applied. ${ }^{20}$ The difficulties in determining, understanding and correctly applying foreign law cannot be understated. ${ }^{21}$

The centrality of the procedural law of the forum in jurisdictional disputes and the wider conception of procedure in the English common law has effectively displaced choice of law concerns from the centre stage of private international law. Moreover, the English common law's pragmatic approach to proof of foreign law offers the litigants a flexible device to evade the choice of law issue altogether and instead rely on domestic English private law. As a result, these forum centric features of English private international law relegate choice of law considerations to a secondary position.

\section{The Emerging Transnationalist Paradigm of Party Autonomy and the Nature of Choice of Law Agreements}

The principle of party autonomy presents itself as a "theoretically unresolved"22 "Gordian knot" $^{23}$ of the conflict of laws at the crux of the procedure/substance, public law/private law

\footnotetext{
${ }^{18}$ In civil law legal systems foreign law is a question of law and the judge is under a duty to establish the foreign law; accordingly, it is not permissible to simply apply the local law (or presume that it is the same). The civil law judge is presumed to know the law, which is well expressed by the Latin adage jura novit curia (the judge knows the law). Moreover, he has the duty to apply the law on the facts, which is expressed by the other famous Latin adage da mihi factum, dabo tibi jus (give me the facts, I will give you the law): S Geeroms, Foreign Law in Civil Litigation (Oxford University Press, 2004) 30-34; See "Foreign law" in Jowitt's Dictionary of English Law (Sweet \& Maxwell, $4^{\text {th }}$ edn, 2015).

${ }^{19}$ See generally, R Fentiman, Foreign Law in English Courts (Oxford University Press, 1998); For a discussion on the sua sponte application of choice of law rules and foreign law: Bogdan (supra n 16) Chapter VI, "Should Conflict Rules and Foreign Law Be Applied Ex Officio?".

${ }^{20}$ A Briggs, The Conflict of Laws (Oxford University Press, 2013) 9.

${ }^{21}$ Lord Mance, "The Future of Private International Law" (2005) 1 Journal of Private International Law 185, 191.

$22 \mathrm{~J}$ Basedow, The Law of Open Societies: Private Ordering and Public Regulation in the Conflict of Laws (Brill Nijhoff, 2015) 115.

${ }^{23}$ SC Symeonides, "General Report" in Private International Law at the End of the 20th Century: Progress or Regress? (The Hague, Kluwer Law International 1999) 1, 38- 40; M Lehmann, "Liberating the Individual from Battles between States: Justifying Party Autonomy in Conflict of Laws" (2008) 41 Vanderbilt Journal of Transnational Law 381, 385.
} 
and international law/national law divides. A deeper and more comprehensive understanding of the concept will further our understanding of the nature and enforcement of choice of law agreements.

It may be asked that if private international law ought to be regarded as essentially and primarily public, systemic and international in character, whether the concept of party autonomy can be satisfactorily reconciled let alone accommodated within this regulatory conception of the discipline. ${ }^{24}$ In other words, if the public rules of private international law are about the allocation of state power, how can individuals grant (by selecting the applicable law in a choice of law agreement) or take away (by ousting the forum's default choice of law rules) the power that properly belongs to states? ${ }^{25}$ Apart from the incompatibility with the multilateral method of closest relationship in private international law, party autonomy also does not fit well with other traditional methods. ${ }^{26}$ This incompatibility may be attributed to traditional conflicts methods being built around the state and its relations. ${ }^{27}$ The concept cannot be justified in a statutist theory because party autonomy is not concerned with the law's own intended scope of application. A theory of acquired or vested rights cannot accommodate party autonomy because when and whether rights are acquired is determined by states and not by parties. It is also incompatible with a focus on governmental interests because governmental interests cannot be determined by private parties. Therefore, party autonomy has been described as the new paradigm of private international law. ${ }^{28}$

Some private international lawyers have traditionally viewed party autonomy as indicating that the only limits on the national regulation of private international law are those concerned with private justice and fairness - concerns which are met if the defendant has freely agreed in advance to the law, even if there are no other objective connections. ${ }^{29}$ If a state applies law in civil proceedings based purely on consent by the parties, this is difficult to reconcile with the traditional public international law requirement that the selected law must be justified by a substantial objective connection, typically territoriality or

\footnotetext{
${ }^{24}$ A Mills, The Confluence of Public and Private International Law (Cambridge University Press, 2009) 291 - 95.

${ }^{25} \mathrm{Cf}$ "How can individuals have a say in the international distribution of legislative competencies?": Lehmann, Liberating the Individual from Battles between States (supra n 23) 412.

${ }^{26}$ See R Michaels, "Party Autonomy in Private International Law--A New Paradigm without a Solid Foundation?" (126th Conference of the Private International Law Association of Japan, 2 June 2013) 2, www.pilaj.jp/data/2013 0602 Party Autonomy.pdf ; R Michaels, "Party Autonomy in Private International Law--A New Paradigm without a Solid Foundation?” (2014) 15 Japanese Yearbook of International Law (forthcoming).

${ }^{27}$ Lehmann, Liberating the Individual from Battles between States (supra n 23) 412.

28 Michaels, Party Autonomy in Private International Law (supra n 26) 3.

${ }^{29}$ Michaels, Party Autonomy in Private International Law (supra n 26) 3, refers to the national private law conception of private international law as the "substantive law" paradigm. The promissory approach to choice of law agreements can be subsumed under the substantive law paradigm.
} 
nationality. ${ }^{30}$ Faced with this argument, it might seem that there are two alternatives: first, rejecting the idea that private international law is about the allocation of regulatory authority between states (denying any connection between public and private international law, thus rejecting the application of choice of law rules to civil disputes, leaving them unrestrained except under national law), or second, making unrealistic arguments against party autonomy based on state interests. ${ }^{31}$

The synthesis of the clash between a substantive law paradigm of party autonomy with no regard for the international allocative function of private international law and an internationalist paradigm of party autonomy which is subordinate to state interests has been described as a "paradigm shift" 32 leading to the emergence of a transnationalist paradigm of party autonomy which will replace the underlying assumptions of the existing paradigms with a new set of foundational principles. ${ }^{33}$

The classification of a choice of law agreement as "factual data" 34 relevant to the application of one of the connecting factors of the lex fori can be subsumed under the internationalist paradigm of party autonomy. The choice of law agreement constitutes a mere factor in the

\footnotetext{
${ }^{30}$ Michaels (ibid), refers to international public law conception of private international law as the "internationalist" paradigm. The objective choice of law rules of the forum are representative of the internationalist paradigm.

${ }^{31}$ Under Beale's First Restatement of Conflict of Laws (1934), party autonomy was rejected because individuals were acting as "legislators". This was an early direct rejection of "individual sovereignty" which encouraged scepticism about rigid private international law rules more generally, contributing to the American "realist" challenge to private international law.

${ }^{32}$ See T Kuhn, The Structure of Scientific Revolutions (University of Chicago Press, 1962); M Van Hoecke and M Warrington, "Legal Cultures, Legal Paradigms and Legal Doctrine: Towards a New Model for Comparative Law" (1998) 47 International and Comparative Law Quarterly 495, 513. For the application of the idea of "legal paradigms" to adjudicatory authority in private international law and how paradigms differ from "principles", "concepts" and "theories", see R Michaels, "Two Paradigms of Jurisdiction" (2006) 27 Michigan Journal of International Law 1003, 1022-27. For a more preliminary distinction between the categories of "rules", "principles" and "policies", see R Dworkin, Taking Rights Seriously (Harvard University Press, 1977) 22- 28.

${ }^{33}$ Michaels, Two Paradigms of Jurisdiction (supra n 32) 1069; McLachlan, Lis Pendens in International Litigation (supra $\mathrm{n} 4$ ) $438-39$, suggests that the contours of a new solution to lis pendens developed as a result of cooperative law reform and driven by the imperatives of globalisation which synthesises the civilian and common law solutions is already upon us. He cites the Leuven/London Principles on Declining and Referring Jurisdiction in Civil and Commercial Litigation (2000), Arts 21 and 22 of the Preliminary Draft Convention on Jurisdiction and Foreign Judgments in Civil and Commercial Matters (30 October 1999), Art 15 of the Brussels Ilbis Regulation and judicial cooperation and communication in matters of insolvency and international child abduction as examples of this development; see also, RA Brand, "Balancing Sovereignty and Party Autonomy in Private International Law : Regression at the European Court of Justice" in J Erauw , V Tomljenovic and P Volken (eds), Universalism, Tradition and the Individual , Liber Memorialis Petar Šarèiviè (Sellier European Law Publishers, 2006) 35 , who discusses traditional concepts of state sovereignty and how those notions fail to account for "the new world of sovereign authority" in private international law where the allocations of authority in multilateral private international law rules have to integrate the expanded recognition of party autonomy; Cf Lehmann, Liberating the Individual from Battles between States (supra $\mathrm{n} 23$ ) 415, refers to the need for a "major paradigm shift" where party autonomy is justified by the individual at the centre of the conflicts problem and state relations that have so far been the focus of the classical theory are ignored.

${ }^{34}$ AE Anton, Private International Law: A Treatise from the Standpoint of Scots Law (SULI/W Green, 1967) 189; AV Dicey, Conflict of Laws (Stevens, $2^{\text {nd }}$ edn, 1908) 820; Cf E Rabel, The Conflict of Laws (University of Michigan Law School, $2^{\text {nd }}$ edn, 1960) 368-369, characterised a choice of law agreement as a "true contract".
} 
determination of the applicable law and has no strict legal effect. ${ }^{35}$ This extra-legal agreement records the mutual or common intention of the parties as to the applicable law, which may or may not be adhered to by the court. Therefore, the exercise of party autonomy under the internationalist paradigm is subordinate to state interests and the objective choice of law rules of the forum.

The classification of choice of law agreements as mutual promises ${ }^{36}$ to sue in a jurisdiction that will apply the law selected in the clause is best represented by the substantive law paradigm of party autonomy. The conception of contracts as the mutual exchange of promises provides the necessary legal basis for a promissory approach to choice of law agreements. ${ }^{37}$ The domestic private law principles of the freedom and sanctity of contract and pacta sunt servanda also lend support to the existence of this obligation and its enforcement. However, the enforcement of this promise within an unrestrained substantive law paradigm may cause untold damage to the reputation of private international law as a structural coordinating framework for the allocation of regulatory authority. The private law enforcement of the mutual contractual obligation not to sue in a forum that will disregard the applicable law selected in a choice of law agreement may operate as a "unilateral private international law rule" with a controversial and confrontational allocative function of its own. It may lead to the "privatization of court access" by dubiously perpetuating and prioritizing the unilateral private ordering of private law over the multilateral public ordering of private law. Moreover, the enforcement of choice of law agreements by private law remedies within a multilateral system will necessarily distort the allocative or distributive function of private international law rules by giving precedence to the redistributive will of the parties premised on principles of corrective justice inter partes of questionable applicability. International structural order is compromised in the unilateral private law enforcement of choice of law agreements as such enforcement gives rise to a clash of sovereign legal orders and also the possibility of "regime collision" by interfering with the jurisdiction, judgments and choice of law apparatus of foreign courts which a multilateral conception of private international law is supposed to prevent in the first place.

A more reconciled transnationalist paradigm of party autonomy will strike a balance between the competing demands of the internationalist and the substantive law paradigms. A conception of a choice of law agreement as a contract, albeit one that does not give rise to any promises inter partes provides an appropriate solution. ${ }^{38}$ On the one hand, the choice of law agreement is a bilateral legal act, or a legally binding agreement as opposed to a

\footnotetext{
${ }^{35}$ Boissevain v Weil [1949] 1 KB 482, 491 (Lord Denning): “I do not believe that parties are free to stipulate by which law the validity of their contract is to be determined. Their intention is only one of the factors to be taken into account."

${ }^{36}$ Briggs, Agreements (supra n 1) 445; See also, Akai Pty Ltd v People's Insurance Co Ltd [1998] 1 Lloyd's Rep 90, 100 (QB) where a choice of law agreement was described as a "bargain"; Cf Ace Insurance Ltd v Moose Enterprise Ltd [2009] NSWSC 724, [47], characterised a choice of law agreement as a "declaratory" act. ${ }^{37}$ See C Fried, Contract as Promise: A Theory of Contractual Obligation (Harvard University Press, 1981). ${ }^{38}$ M Hook, The Choice of Law Contract (Hart Publishing, 2016) Chapter 2, arrives at a very similar conclusion regarding the nature and classification of choice of law agreements as this author.
} 
mere "factual" agreement. On the other hand, the function of this agreement is not to create or modify rights and obligations: it is to opt out of the forum's objective choice of law rules and to choose the applicable law. The fact that the choice of law agreement is a contract, which only gives rise to procedural consequences, does not mean that it is not, or should not be, described as a contract. ${ }^{39}$ A consent-based theory of contract thus treats as the core of contract a manifest intention to be legally bound. ${ }^{40}$

\section{The Promissory Classification of Choice of Law Agreements and its Discontents}

Under the proper law doctrine of the English common law, a court gives effect to an express choice of law, as long as it is bona fide, legal and not contrary to public policy. ${ }^{41}$ Hence, the entitlement of the parties to select the governing law is not absolute and there are limitations on it. ${ }^{42}$ The Rome Convention on the law applicable to contractual obligations replaced the English common law's proper law doctrine on 1 April $1991 .{ }^{43}$ For contracts concluded after 17 December 2009, ${ }^{44}$ the Rome I Regulation applies to cases involving a contractual obligation in civil and commercial matters litigated before an English court and involving a choice between the laws of different countries. ${ }^{45}$

Drawing an analogy with arbitration and choice of court agreements, Briggs argues that choice of law agreements have two functions. The first is to identify the proper law of the contract. The second emanates from the promissory effect of a choice of law agreement and is concerned with the consequences of breaching a choice of law agreement. Therefore, "a choice of law clause may be interpreted as telling a court what it needs to know to adjudicate the dispute under the contract, and as each party telling the other what promises are made as to the law which will be applied to the contract". ${ }^{46}$ Ascribing the negative aspect of an arbitration agreement and exclusive choice of court agreement ${ }^{47}$ to choice of

\footnotetext{
${ }^{39}$ For a similar argument in relation to choice of court agreements as "procedural contracts" under the Brussels la Regulation, see, M Ahmed, The Nature and Enforcement of Choice of Court Agreements: A Comparative Study (Hart Publishing, 2017) 76-82.

${ }^{40}$ R Barnett, "A Consent Theory of Contract" (1986) 86 Columbia Law Review 269; RE Jones and G MacCormack, “Obligations” in E Metzger (ed), A Companion to Justinian's Institutions (London, Duckworth, 1998) 127, 150.

${ }^{41}$ Vita Food Products Ltd v Unus Shipping Co Ltd [1939] UKPC 7, [1939] AC 277 (Lord Wright) There is no reported English decision in which an express choice was disapplied on the basis of the provisio. See J Hill and MN Shuilleabhain, Clarkson and Hill's Conflict of Laws (Oxford University Press, $5^{\text {th }}$ edn, 2016) 212.

${ }^{42}$ Ace Insurance Ltd v. Moose Enterprise Pty Ltd [2009] NSWSC 724, [52] (Brereton J).

${ }^{43}$ The Rome Convention 1980 on the law applicable to contractual obligations (OJ C 27, 26.1.1998, p 36-53) was enacted into law by the Contracts (Applicable Law) Act 1990 in the UK.

${ }^{44}$ Articles 28 and 29 of the Rome I Regulation.

${ }^{45}$ Article 1(1) of the Rome I Regulation.

${ }^{46}$ Briggs, Agreements (supra n 1) 436 (emphasis in original).

${ }^{47}$ For the negative aspect of an arbitration agreement and exclusive choice of court clause See, UstKamenogorsk Hydropower Plant JSC v AES Ust-Kamenogorsk Hydropower Plant LLP [2013] UKSC 35, [2013] 1 WLR 1889; [2013] 1 CLC 1069, [21]-[28] (Lord Mance with whom Lord Neuberger, Lord Clarke, Lord Sumption and Lord Toulson agreed).
} 
law agreements, Briggs suggests that a choice of law clause in favour of State X may be reinterpreted to connote both an agreement that, if a dispute arises, the claimant will contend that the parties' relationship is governed by the law of State X; but also an agreement between the parties that no law other than the law of State $X$ shall govern their relationship. ${ }^{48}$

An express choice of law agreement specifies the applicable law of a contract. ${ }^{49}$ The substantive rights and obligations of the parties to the contract will be determined by reference to the applicable law. ${ }^{50}$ However, the court seised with jurisdiction may not apply the selected law for a number of reasons - whether because its choice of law rules directed the judge to apply a different law; or its own choice of law rules, while accepting the right of the parties to choose the applicable law, regarded the particular choice as impermissible; or that the court was directed by its own choice of law rules to apply mandatory domestic law or public policy; or that the court errs in its application of the chosen law. A controversial issue is whether adherence to a governing law clause may be enforced by an action for breach of contract. ${ }^{51}$

In other words, the legal basis of an action for breach of a choice of law agreement hinges on the appropriate classification of a choice of law agreement. Is the appropriate classification of a choice of law agreement "promissory" or "declaratory" in nature? A decision of the New South Wales Supreme Court (Australia) has brought this issue to the fore and has tested the viability of Briggs' ideas regarding breach of choice of law agreements in a practical context. Ace Insurance v. Moose Enterprise Pty $L t d^{52}$, is probably the first common law decision to consider whether proceedings in a foreign court could constitute breach of a choice of law agreement. ${ }^{53}$ In the words of Briggs this is "territory into which the English courts have not [yet] been invited to go". ${ }^{54}$

One of the arguments advanced by counsel for the claimant in that case was that by commencing Californian proceedings for the purposes of taking advantage of Californian law, the defendant had broken the implied promise arising from the Australian choice of law clause, and that an anti-suit injunction should be issued to restrain this breach. In support of this novel argument, the counsel for the claimant relied on the suggestions of Briggs in

\footnotetext{
${ }^{48}$ Briggs, Agreements (supra n 1) 439.

${ }^{49}$ Article 3(1) of the Rome I Regulation recognises the principle of party autonomy as one of the cornerstones of the European system of conflict of law rules in matters of contractual obligations (Recital 11 of the Rome I Regulation); See Article 14 and Recital 31 of the Rome II Regulation.

50 See Article 12 of the Rome I Regulation.

${ }^{51}$ Briggs, Agreements (supra n 1) 446-453.

${ }^{52}$ Ace Insurance Ltd v. Moose Enterprise Pty Ltd [2009] NSWSC 724 (Brereton J); P Herzfeld, "Choice of Law Clauses are not Promissory", see, http://conflictoflaws.net/2009/choice-of-law-clauses-are-not-promissory/ accessed 24 November 2017.

53 TM Yeo, "Breach of Agreements on Choice of Law" [2010] Lloyd's Maritime and Commercial Law Quarterly 194, 194.

${ }^{54}$ Briggs, Agreements (supra n 1) 424.
} 
Agreements. ${ }^{55}$ Brereton, J. observed that the submission was premised on the proposition that the choice of law agreement was promissory in effect and held:

No doubt a contractual provision could be framed which unambiguously contained a promise to do nothing that might result in some other system of law becoming applicable. However, in my opinion that is not ordinarily the effect of a choice of law clause, which is usually declaratory of the intent of the parties, rather than promissory. ${ }^{56}$

In our system of private international law, therefore, choice of law is about ascertaining the intention of the parties as to the legal system that is to govern their contract, not about covenants or promises that a particular legal system will apply.....It may well be that the parties could frame a provision which was promissory in effect, but - given the conventional function of a choice of law clause - it would require very clear language to make it promissory rather than declaratory. ${ }^{57}$

Although Brereton, J. acknowledged the possibility of an appropriately framed choice of law clause using "very clear language" leading to a promissory effect, he nevertheless refused to give effect to the clause in the instant case by relying on the conventional declaratory function of such clauses. ${ }^{58}$ The path well-trodden was chosen and rightly so considering the dearth of judicial authority and a lack of academic consensus for the novel interpretation of choice of law agreements advanced by Briggs.

The promissory effect of a choice of law agreement was also examined by the English Commercial Court in The Lucky Lady. ${ }^{59}$ In that case, Navig8 (a Singaporean company) sought permission to serve Al-Riyadh (a Jordanian company) out of the jurisdiction, on the basis that proceedings brought by Al-Riyadh in Jordan were contrary to a choice of English law. AlRiyadh claimed damages from Navig8 as the alleged carrier of damaged cargo. The bill of lading provided for English law. Pursuant to Jordanian choice of law rules, however, the law governing the dispute was Jordanian law. In the English court, Navig8 sought an anti-suit injunction, damages and a negative declaration that it was not a party to the contracts of carriage. It argued that, because English law contained certain protections that were not available to it under Jordanian law, the Jordanian proceedings were "designed to defeat....their rights under English law" ${ }^{60}$

\footnotetext{
55 Ibid Chapter 11.

${ }^{56}$ Ace Insurance Ltd v. Moose Enterprise Pty Ltd [2009] NSWSC 724, [47] (Brereton J) (emphasis added).

${ }^{57}$ Ace Insurance Ltd v. Moose Enterprise Pty Ltd [2009] NSWSC 724, [51] (Brereton J) (emphasis added).

58 Ibid; Yeo, Breach of Agreements on Choice of Law (supra n 53) 196.

${ }^{59}$ Navig8 Pte Ltd v Al-Riyadh Co for Vegetable Oil Industry ("The Lucky Lady") [2013] EWHC 328 (Comm), [2013] 2 Lloyd's Rep 104, [2013] 2 CLC 461 (Andrew Smith J).

60 lbid [16].
} 
The English court rejected the applications for an anti-suit injunction and damages, on the basis that, by commencing the Jordanian proceedings, Al-Riyadh did not contravene "any (contractual or other) duty owed to Navig8". ${ }^{61}$ The court found that in effect Navig8 was claiming: ${ }^{62}$

a right, deriving apparently from the choice of English law, not to be sued in any jurisdiction that does not give effect to a choice of English law that is recognised by English private international law, at least unless the foreign jurisdiction recognises rights similar to those recognised by English law.

The court held that: "There is no proper basis for so wide a proposition". ${ }^{63}$ Nevertheless, the court was willing to grant permission for leave to serve out of the jurisdiction the claims for declaratory relief, concluding that England was the proper place for these claims because of the parties' choice of English law.

Therefore, the English High Court in The Lucky Lady was quick to reject a submission that the English choice of law agreement conferred a right on the applicant to be sued in a forum that would give effect to it. ${ }^{64}$ This ruling has confirmed the previous finding of the New South Wales Supreme Court in Ace Insurance Ltd $v$ Moose Enterprise Pty Ltd that an ordinary choice of law agreement did not "found implied negative stipulations" as to jurisdiction. ${ }^{65}$

Takahashi also doubts whether a choice of law agreement could entail a promissory effect. ${ }^{66}$ He argues that in most cases, a choice of law clause does not contain an express undertaking not to bring an action in a court, which would deny effect to it. Therefore, it is even more difficult to read such an implied undertaking into a choice of law clause. He concludes that a contractual claim seeking damages for breach of a choice of law clause should not be allowed unless the agreement contains an express undertaking not to bring an action in a court, which would deny effect to it. It is submitted, that the conventional wisdom in the dicta of Brereton, J. in the Ace Insurance decision is reflected in Takahashi's views.

Basedow starts his inquiry into the binding effect of choice of law agreements by highlighting that "an inappropriate commingling of different types of contracts" has

\footnotetext{
61 Ibid [22].

62 Ibid [22].

63 Ibid [22].

${ }^{64}$ As opposed to the breach of a legal right or breach of contract in suing before a court which will not give effect to an express choice of law by the parties, it is not wrongful to sue in a court which will apply principles of private international law which are merely different from those applicable in an English court. See Erste Group Bank AG v JSC ("VMZ Red October") [2013] EWHC 2926 (Comm) (Flaux J); A Briggs, Private International Law in English Courts (Oxford University Press, 2014) 400.

${ }^{65}$ Ace Insurance Ltd v. Moose Enterprise Pty Ltd [2009] NSWSC 724, [53] (Brereton J).

${ }^{66} \mathrm{~K}$ Takahashi, "Damages for Breach of a Choice of Court Agreement: Remaining Issues" (2009) 11 Yearbook of Private International Law 73, 101-102.
} 
occurred. ${ }^{67}$ He submits that a choice of law agreement is of a different nature from an unfulfilled contract in which there is a mutual exchange of promises as to future conduct. He maintains that choice of law agreements are self-fulfilling dispositional contracts. ${ }^{68}$ The effect of the agreement was realised at the moment it was jointly adopted by the parties. The contract embodies a dispositional character in that it disposes off the assignment of the contract to one of the several hundred legal orders found across the world. Hook classifies choice of law agreements as contracts for the disposition of the default choice of law norms. ${ }^{69}$ These positions are in contrast to the classification adopted by Briggs, which conceives choice of law agreements as part of a comprehensive dispute resolution agreement regulating the future conduct of the parties. ${ }^{70}$ It should be noted that both Basedow and Hook treat choice of law agreements as executed contracts whereas Briggs conceptualises them as executory contracts. ${ }^{71}$

Fentiman comments on the possible promissory nature of choice of law agreements with: "It is unclear how it assists to view the matter in contractual terms."72 He argues that it cannot be a breach to invite a court to characterise a given issue as one not falling within the scope of the agreed law, such as the law of the forum (lex fori). Such an allegation does not in any way deny that the contractual law governs matters to which it properly applies. A simple choice of law clause is not an agreement that the law agreed upon governs each and every aspect of the dispute. Moreover, if such a clause were to provide that the chosen law governs every aspect of a dispute it would be presumably ineffective. He concludes by stating that, the parties cannot by choice oust the private international law rules of the forum. ${ }^{73}$

\footnotetext{
${ }^{67}$ Basedow, The Law of Open Societies (supra n 22) 145; J Basedow, "The Law of Open Societies - Private Ordering and Public Regulation of International Relations" (2012) 360 Recueil des Cours, 199-200; Cf Michaels, Party Autonomy in Private International Law (supra n 26) 8, notes that a choice of law agreement as a "disposition" is similar in effect to an "obligation" arising from the clause as both operate within the substantive law paradigm.

${ }^{68}$ Basedow, The Law of Open Societies (supra n 22) 145.

${ }^{69}$ Hook, The Choice of Law Contract (supra n 38) 41. For a parallel discussion of the fundamental juridical nature and classification of choice of court agreements as "procedural contracts" under the Brussels la Regulation see, Ahmed, The Nature and Enforcement of Choice of Court Agreements (supra n 39) 76-82.

${ }^{70}$ Cf J Harris, "Agreements on Jurisdiction and Choice of Law: Where Next?" [2009] Lloyd's Maritime and Commercial Law Quarterly 537, 549, doubts the view that choice of law agreements are dispute resolution agreements by referring to their significant role in transaction planning prior to actual litigation.

71 "Where nothing remains to be done by either party, and where the transaction is completed at the moment that the agreement is made, as where an article is sold and delivered, and payment therefor is made on the spot. A contract is said to be executory where some future act is to be done, as where an agreement is made to build a house in six months, or to do an act on or before some future day, or to lend money upon a certain interest, payable at a future time.": "Executed contract" in Jowitt's Dictionary of English Law (supra n 18).

72 Fentiman, International Commercial Litigation (2015) (supra n 1) 129; R Fentiman, International Commercial Litigation (Oxford University Press, 2010) 106.

73 Ibid; Cf Lehmann, Liberating the Individual from Battles between States (supra n 23) 419 - 21, operates within the "substantive law" paradigm and proposes the new category of "relatively mandatory rules" which cannot be deviated from in a national context but may be opted out of with regard to parties' choice from an international perspective; Briggs, Agreements (supra n 1) 7: "[t]he instances in which the intention of the
} 
Borrowing HLA Hart's terminology, in the "core"74 case of exclusive choice of court agreements in the English common law there is an express duty to bring proceedings only in the contractual forum and a correlative ${ }^{75}$ right of the counterparty not to be sued in the non-elected forum. There is no such express duty to bring proceedings in a forum that will give effect to the choice of law agreement or a correlative right not to sued in a forum that will defeat the choice of law clause in the more doubtful "penumbra" ${ }^{76}$ case of choice of law agreements. ${ }^{77}$ Building on this interpretation, the breach of a choice of law agreement may not be enforced by either party and the choice of law agreement is simply an unequivocal expression of the law, which the parties intend shall govern their contractual relationship. ${ }^{78}$ This may or may not be applied by a court faced with a dispute relating to the contract. It has also been argued that choice of court and choice of law agreements fundamentally differ from each other because if a court does not choose to apply the law specified in the choice of law agreement it is more difficult to conclude that either party is at fault: ${ }^{79}$ "It is in fact impossible to say that either contracting party breached his promise contained in the choice-of-law clause." The situation with respect to choice of court agreements differs in that a choice of court agreement can only be breached where one party willfully institutes proceedings in a non-contractual forum. ${ }^{80}$ The choice of court clause can only be breached by the deliberate act of one party. ${ }^{81}$

Non-exclusive choice of court agreements generally carry no promise not to sue in other jurisdictions. ${ }^{82}$ However, the English Court of Appeal has reminded us that it is ultimately a question of construction of the contract what promises the parties may have made in

parties may be overridden should be few and ... should be taken less seriously when parties agree to bring their disputes before a court".

${ }^{74}$ HLA Hart, The Concept of Law (2 ${ }^{\text {nd }}$ Ed, Clarendon Press, Oxford University Press, 1994) 121-150; HLA Hart,

"Positivism and the Separation of Law and Morals" (1958) 71 Harvard Law Review 593.

${ }^{75}$ For the jural correlative concepts of right and duty see, WN Hohfeld, "Fundamental Legal Conceptions as Applied in Judicial Reasoning" (1917) Yale Law School Faculty Scholarship Series (Paper 4378), http://digitalcommons.law.yale.edu/fss papers/4378/ accessed 24 November 2017; EJ Weinrib, The Idea of Private Law (Oxford University Press, 2012) Chapter 5, "Correlativity".

${ }^{76}$ Hart, The Concept of Law (supra n 74) 121-150; Hart, Positivism and the Separation of Law and Morals (supra n 74).

77 Ace Insurance Ltd v. Moose Enterprise Pty Ltd [2009] NSWSC 724, [47] (Brereton J); Yeo, Breach of Agreements on Choice of Law (supra n 53) 195.

${ }^{78}$ A Dickinson, "Restitution and Incapacity: A Choice of Law Solution?" [1997] Restitution Law Review 66, 69 FN 26; D Tan and N Yeo, "Breaking Promises to Litigate in a Particular Forum: Are Damages an Appropriate Remedy" [2003] Lloyd's Maritime and Commercial Law Quarterly 435, 437 FN 8.

79 D Tan, "Damages for Breach of Forum Selection Clauses, Principled Remedies, and Control of International Civil Litigation" (2005) 40 Texas International Law Journal 623, 650.

80 Ibid.

81 Ibid 651.

${ }^{82}$ Ace Insurance Ltd v. Moose Enterprise Pty Ltd [2009] NSWSC 724, [15] (Brereton J); J Fawcett, "Non exclusive jurisdiction agreements in private international law" [2001] Lloyd's Maritime and Commercial Law Quarterly 234, 253. 
respect of a non-exclusive choice of court agreement. ${ }^{83}$ Non-exclusive jurisdiction agreements may be the foundation for an anti-suit injunction to protect a contractual right if the conduct of foreign proceedings amounts to breach of an implied agreement not to bring such proceedings once proceedings have commenced in the non-exclusive but primary jurisdiction, ${ }^{84}$ or if it amounts to the breach of an implied agreement because it (being a foreign anti-suit injunction action) attempts to restrain the exercise of a contractual right to commence proceedings in the non-exclusively chosen forum at all. ${ }^{85}$ The analogy with nonexclusive jurisdiction agreements emphasises that ultimately it is a question of construction what promises may be inferred from the parties in the contract. ${ }^{86}$ In similar vein, it has been argued that whether or not a choice of law agreement is promissory in nature is, in the final analysis, an issue of construction. ${ }^{87}$ Brereton $\mathrm{J}$ also recognised that the issue is one of contractual construction ${ }^{88}$ and the intentions of the contracting parties are very significant in that regard. ${ }^{89}$

The inherent value and necessary implications of a promissory choice of law agreement also need to be carefully examined. A promissory choice of law agreement comes close to being treated as an exclusionary jurisdiction agreement or an implied agreement to exclude the jurisdiction of the choice-defeating forum. It is a matter of concern that this development has proceeded without any consideration of the principles and rules that would usually govern an agreement of this kind..$^{90}$ Exclusionary jurisdiction agreements that are implied from choice of law agreements fall short of the standard ordinarily required of choice of court agreements.

It is submitted that, the "promise" in the choice of law agreement should not be enforced because the enforcement of an implied intention to derogate from the jurisdiction of the choice defeating courts is inconsistent with the principles and rules that govern jurisdictional party autonomy more generally. In New Hampshire Insurance Co v Strabag Bau $A G$, the Court of Appeal held that the requirements of Article 17 of the Brussels Convention

\footnotetext{
${ }^{83}$ Highland Crusader Offshore Partners LP v Deutsche Bank AG [2009] EWCA Civ 725; Royal Bank of Canada v Cooperative Centrale Raiffeisen-Boerenleenbank [2004] EWCA Civ 7, [2004] 1 Lloyd's Rep 471; Fawcett (supra n 82) 235-236.

${ }^{84}$ See, eg, BP Plc v Aon Ltd [2005] EWHC 2554 (Comm), [2006] 1 Lloyd's Rep 549, [31]; Royal Bank of Canada v Cooperative Centrale Raiffeisen-Boerenleenbank [2004] EWCA Civ 7, [2004] 1 Lloyd's Rep 471, [24]-[25].

${ }^{85}$ See, eg, Sabah Shipyard (Pakistan) Limited v Islamic Republic of Pakistan [2003] 2 Lloyd's Rep 571; Highland Crusader Offshore Partners LP v Deutsche Bank AG [2009] EWCA Civ 725, [112].

${ }^{86}$ Yeo, Breach of Agreements on Choice of Law (supra $n$ 53) 196.

87 Ibid; A Briggs and P Rees, Civil Jurisdiction and Judgments (Informa Law from Routledge, $5^{\text {th }}$ edn, 2009) 625; Briggs, Agreements (supra n 1) 451.

${ }^{88}$ Ace Insurance Ltd v. Moose Enterprise Pty Ltd [2009] NSWSC 724, [51] (Brereton J).

${ }^{89}$ See Fiona Trust \& Holding Corp v Privalov [2007] UKHL 40; [2007] 2 CLC 553; [2008] 1 Lloyd's Rep 254, [27] (a decision on arbitration agreements) where Lord Hope of Craighead stated that the same interpretive approach should be adopted in relation to choice of law and jurisdiction agreements.

${ }^{90}$ Hook (supra n 8) 970.
} 
could only be met by a valid choice of court agreement. ${ }^{91}$ By excluding a forum, the parties forsake their right of access to justice in that particular forum and the parties should be aware of the consequences of their decision. However, it is now clear that as a matter of English common law conflicts principles there does not have to be an express contractual agreement (or indeed any formal contractual agreement) to submit but that consent can be express or implied. ${ }^{92}$

An exclusionary jurisdiction agreement imputed from a choice of law agreement is neither express nor in most cases real. It is an implied term of the choice of law agreement that is based on the hypothetical or presumed intention of the parties: an agreement that the parties would have reasonably concluded if they had considered the matter. It is submitted that, parties should not be deprived of the ability to litigate in available jurisdictions on the basis of an imputed intention. As a matter of principle, a more stringent and objectively verifiable standard along the lines of the requirements for prorogation of jurisdiction should be a necessary pre-requisite for parties to effectively derogate from the jurisdiction of the available choice of law defeating courts.

Furthermore, conceiving choice of law agreements from a purely promissory perspective ignores the very significant role of the law of the forum including its mandatory choice of law regime..$^{93}$ If a choice of law agreement is accompanied by an agreement to the exclusive jurisdiction of a given court, this presumably constitutes an agreement that the conflicts rules of the forum shall apply, including those giving effect to any choice of law clause. If such a clause is tied to a non-exclusive jurisdiction agreement or contains no jurisdiction agreement at all, this suggests that the parties are content that the effect of the clause is subject to the conflicts rules of any court seised of proceedings.

Implied choice of law under Article 3(1) of the Rome I Regulation is a potential source of difficulty for those arguing that a choice of law agreement is promissory in nature. ${ }^{94}$ Article $3(1)$ provides that the choice shall be "clearly demonstrated by the terms of the contract or the circumstances of the case." Where the choice of law is implied rather than express, it is not conceivable that there would be an implied negative stipulation not to invoke the jurisdiction of a court, which would apply a law other than the chosen one. It is submitted that, this line of reasoning supports the conclusion that where there is an express choice of law agreement, there is similarly no implied obligation not to invoke the jurisdiction of a court, which will not apply the chosen law. Therefore, the express choice of law in a choice

\footnotetext{
${ }^{91}$ New Hampshire Insurance Co v Strabag Bau AG [1992] 1 Lloyd's Rep 361, 371-372 (CA); For a discussion of the formal validity requirements of a choice of court agreement under the Brussels I Regulation, see, PR Beaumont and PE McEleavy, Anton's Private International Law (SULI/W Green, $3^{\text {rd }}$ edn, 2011) 242-249.

92 Vizcaya Partners Limited v Picard and another [2016] UKPC 5 (Lord Collins); Cf For the position prior to the Privy Council decision, see L Collins and others (eds.), Dicey, Morris and Collins on the Conflict of Laws (Sweet and Maxwell, 15 ${ }^{\text {th }}$ edn, 2012) para 14-079: "It may be laid down as a general rule that an agreement to submit to the jurisdiction of a foreign court must be express: it cannot be implied."

${ }^{93}$ See Bogdan (supra $n$ 16) Chapter II.

${ }^{94}$ See Article 4 of The Hague Principles on Choice of Law in International Commercial Contracts (supra $\mathrm{n}$ 14).
} 
of law agreement declares the intention of the contracting parties and is not promissory. The provision on party autonomy in the Rome I Regulation includes both express and implied choice within the same rule. This further suggests that an internally consistent and internally coherent application of Article 3(1) of the Rome I Regulation requires that both express and implied choice of law be interpreted as specifying the applicable law and as not supporting the conception of choice of law agreements as promissory contracts between the parties to abide by the stipulated law. In the Ace Insurance decision, Brereton J used a similar argument to demonstrate that it cannot be a breach of contract to sue in a forum, which will not give effect to an "inferred" choice of law. ${ }^{95}$ The promissory nature of a choice of law agreement is most plausible where there is a governing law clause and less so where the law chosen by the parties is identified from other terms of the contract or from their conduct. ${ }^{96}$ Furthermore, Article 3(2) of the Rome I Regulation provides that: "The parties may at any time agree to subject the contract to a law other than that which previously governed it". ${ }^{97}$ Therefore, the subsequent agreement of the parties as to choice of law will override the choice of law agreement and any promises that arise from it.

In order to understand the relative autonomy of choice of law agreements and their functional dependence on the law of the forum it is necessary to delve deeper into the theoretical basis for party autonomy in choice of law. Nygh examines the source of party autonomy in Autonomy in International Contracts: what gives the parties permission to make a choice in the first place ${ }^{98}$ First, he considers the situation where the will of the parties is truly autonomous and supreme..$^{99}$ In this scenario, the parties may choose to have the contract not governed by any law at all, or by the international principles of private law (lex mercatoria). If they do choose a municipal system of law they cannot be bound by subsequent changes in the law unless they agreed to be so bound. They can also contract themselves out of the operation of its mandatory rules including international mandatory rules and the public policy of the forum. However, Nygh remarks that a "free floating" choice of law where the parties' will is truly autonomous and supreme "does not as yet have much support". ${ }^{100}$ On the other hand, the choice of the parties must be based on the private international law rules of a particular municipal legal system and the scope of that choice of law will be necessarily limited by the operation of the mandatory rules and public policy of the forum.

\footnotetext{
${ }^{95}$ Ace Insurance Ltd v. Moose Enterprise Pty Ltd [2009] NSWSC 724, [51] (Brereton J); Yeo, Breach of Agreements on Choice of Law (supra n 53) 196.

96 Dickinson, Restitution and Incapacity: A Choice of Law Solution? (supra n 78) 69.

${ }^{97}$ See Article 2(3) of The Hague Principles on Choice of Law in International Commercial Contracts (supra $\mathrm{n}$ 14); The pragmatic approach to "foreign law" adopted by the English courts may lead to the application of English law by the consent of the parties can be viewed as an example of subsequent choice of law under Article 3(2) of the Rome I Regulation, see supra n 18-21.

98 PE Nygh, Autonomy in International Contracts (Oxford University Press, 1999) Chapter 2, 31-45.

${ }^{99}$ Ibid 31-32.

100 Ibid 32.
} 
Nygh then goes on to trace the source of party autonomy in national municipal legal systems. ${ }^{101}$ Ehrenzweig expressed the prevailing majority view when he stated: "Party autonomy is, of course, not an independent source of conflicts rules, but is effective only in so far as it is recognised by such a rule". ${ }^{102}$ In fact, Ehrenzweig went to the extent that he described this proposition as a "truism". ${ }^{103}$ Therefore, party autonomy is only effective if it is inserted as a connecting factor in the relevant municipal choice of law rule. It is submitted, that party autonomy can only operate through the choice of law rules of a national legal system and that the law of the forum must provide the necessary entry point for this autonomy to be exercised.

With regard to Article 3(1) 104 of the Rome Convention, Nygh cites Paul Lagarde (one of the rapporteurs of the official accompanying report: the Giuliano-Lagarde Report) as stating that: "Ce choix est un choix de droit international prive"105 ("This choice is a choice of private international law"106). Therefore, when the parties enter into a contract in relation to the applicable law they are also agreeing to be bound by the mandatory private international law rules of the Rome Convention and its successor the Rome I Regulation that actually give effect to the choice of the parties and regulate or delimit the operation of the chosen law.

Nygh explains that the concept underlying the search for an authorizing national law, particularly the law of the forum, is the ancient idea of the territorial sovereignty of the nation state and its ability to command its courts. ${ }^{107}$ On this view, any freedom that the parties may possess is one granted by the sovereign. This view of party autonomy as being predicated on the territorial sovereignty of the nation state has metamorphosed into the increasingly multi-dimensional and international private international law rules of the EU conflicts regime.

Nygh also examines international law or custom as a source of party autonomy. ${ }^{108}$ In this regard, Lowenfeld has stated that "it is fair to say....that party autonomy- both for choice of law and for choice of forum, including an arbitral forum- is now part of an international customary law of dispute settlement" ${ }^{109}$ An international basis for party autonomy is also supported by the Institute of International Law. ${ }^{110}$ Ralf Michaels cites this 1991 resolution of

\footnotetext{
101 ibid 32-35.

102 AA Ehrenzweig, Private International Law (Volume I, Sijthoff, 1972) 44.

103 Ibid.

104 "A contract shall be governed by the law chosen by the parties. The choice must be expressed or demonstrated with reasonable certainty by the terms of the contract or the circumstances of the case. By their choice the parties can select the law applicable to the whole or a part only of the contract."

105 Nygh (supra n 98) 33.

106 Translation by author.

107 Nygh (supra n 98) 35.

108 Ibid 35-37.

${ }^{109}$ AF Lowenfeld, International Litigation and the Quest for Reasonableness: Essays in Private International Law (Clarendon Press, Oxford University Press, 1996) 208-209.

110 International Law Institute, "Autonomy of the Parties in International Contracts Between Private Persons or Entities" (1991); Annuaire de l'institut de droit international, Session de Bale (1992) Volume 64-II, 208
} 
the Institute of International Law as supporting the contention that party autonomy should be based on the notion of human rights. ${ }^{111}$ Jayme explains that the foundation of party autonomy lies in the principle of liberty of the individual which is a part of Human Rights, as proclaimed most prominently in the Universal Declaration of Human Rights of 10 December 1948, which applies not merely in the personal but also in the economic sphere. ${ }^{112}$ On that view, the freedom to choose the applicable law is not merely a connecting factor; it is the parties who insert their agreement in to the legal system they have freely chosen. In other words, the "sovereignty of the individual" is recognised in an increasingly pluralistic and cosmopolitan international legal order. ${ }^{113}$ In brief, "Rules of private international law strike a balance between facilitating internationally recognised individual autonomy and respect for state regulatory authority - between individual freedom and collective cultural identity."114

Writing at the turn of the millennium, Nygh concludes that there is still general support for the proposition that the law of the forum (including its choice of law rules) must provide the authorization for the parties to "exit" the otherwise applicable law or the jurisdiction of the competent court. ${ }^{115}$ However, in the context of the increasingly important and ever burgeoning European private international law regime, the Brussels Ia, ${ }^{116}$ Rome I and II Regulations provide uniform international rules for civil jurisdiction and choice of law matters, which form part of the law of the forum. Therefore, matters which are subject to and governed by the supra-national European conflicts regime may be more readily explained by a combination of the international justification for party autonomy and the justification predicated on the territorial sovereignty of the nation state. Nygh does recognise that the right of the parties to choose the applicable law represents a rule of international customary law. ${ }^{117}$

It is the mandatory choice of law rules of the forum that characterise a given issue as procedural or substantive. The Rome I and II Regulations adopt a direct approach by subjecting particular issues to the applicable law of the contractual or non-contractual obligation. ${ }^{118}$ The instruments exclude matters relating to "evidence and procedure" 119 from their scope and lack any autonomous definition for these terms. The result is that national law will have to be applied to determine both the meaning given to these terms and what law should be applied to an individual issue (assuming that the matter has not been directly

\footnotetext{
${ }^{111}$ R Michaels, "Public and Private International Law: German Views on Global Issues" [2008] Journal of Private International Law 121, 132.

112 E Jayme, « Identite culturelle et integration: le droit international prive postmoderne », 251 Recuil des

Cours (1995-I) 9, 147-148 in Nygh (supra n 98) 36.

113 Mills, The Confluence (supra n 24) 291-295.

114 Mills, The Confluence (supra n 24) 294.

115 Nygh (supra n 98) 44.

${ }^{116}$ Council Regulation (EU) 1215/2012 of the European Parliament and of the Council of 12 December 2012 on jurisdiction and the recognition and enforcement of judgments in civil and commercial matters (recast) [2012]

OJ L351/1. (“Brussels la Regulation”)

117 Ibid 45.

${ }^{118}$ Article 12 of the Rome I Regulation; Article 15 of the Rome II Regulation.

${ }^{119}$ Article 1(3) of the Rome I Regulation; Article 1(3) of the Rome II Regulation.
} 
subjected to the applicable law by the Regulations). Considerable scope of operation is therefore left to national choice of law rules under the Regulations. Some commentators, in particular Illmer, have criticised this position, stating that the application of national law to matters of evidence and procedure, where the law of the cause of action falls under the Regulations, will lead to disharmony of court decisions and is incompatible with a European system of private international law. ${ }^{120}$ Illmer argues that an autonomous conception of "evidence and procedure" is required, based on the idea of "neutrality", 121 which means that a national court must apply the law of the cause of action to any issue which is concerned with or directed at the decision on the merits and which requires the law of the forum to be applied to any matter which concerns the mode or conduct of court proceedings. Garnett argues that whether or not an autonomous definition of procedure is adopted in relation to matters not considered by the Regulations, procedure should be based on the narrow mode and conduct of court proceedings view espoused by the Australian courts ${ }^{122}$ rather than the traditional right-remedy test. ${ }^{123}$ Following the lex fori regit processum ${ }^{124}$ rule, the law of the forum applies to matters of procedure and the applicable law applies to matters of substance.

Therefore, it cannot conceivably be a breach to invite a court to characterise an issue as one falling within the domain of procedure and outside the proper and legitimate scope of the agreed applicable law. As discussed above, national courts have the responsibility of defining the categories of procedure and substance and allocating a particular issue to either category. A conventional choice of law agreement is not an agreement that the law agreed upon will govern each and every aspect of a dispute. Such an agreement would presumably be ineffective as the parties cannot by agreement oust the mandatory choice of law rules of the forum.

The doctrine of renvoi may also supply courts the judicial discretion to avoid the foreign applicable law and apply the law of the forum instead. ${ }^{125}$ However, in the most significant commercial areas of private international law that dominate the discipline the use of renvoi

\footnotetext{
${ }^{120}$ M IIImer, "Neutrality Matters - Some Thoughts About the Rome Regulations and the so called Dichotomy of Substance and Procedure in European Private International Law" (2009) 28 Civil Justice Quarterly 237; Dickinson sees the concepts of evidence and procedure as "matters that define the scope of the Regulation" which must therefore be given a uniform, autonomous meaning, independent of the forum's notions: $A$ Dickinson, The Rome I/ Regulation (Oxford University Press, 2008) para 14.57.

121 Illmer, Neutrality Matters (supra n 120) 246-247.

122 McKain v RW Miller and Co (South Australia) Pty Ltd (1991) 174 CLR 1; John Pfeiffer Pty Ltd v Rogerson (2000) 203 CLR 503.

${ }^{123}$ Garnett, Substance and Procedure in Private International Law (supra $\mathrm{n}$ 16) 39; Dickinson also suggests the adoption of a test on similar lines: Dickinson, Rome I/ Regulation (supra $\mathrm{n}$ 120) para 14.60; Briggs and Bogdan too express dissatisfaction with the traditional English approach that remedies are a matter of procedure to be governed by the lex fori: Briggs, The Conflict of Laws (supra $\mathrm{n} 20$ ) 193; Bogdan, Private International Law as Component of the Law of the Forum (supra n 16) Chapter VIII, 194.

124 "the law of the forum governs procedure": See Garnett, Substance and Procedure in Private International Law (supra $\mathrm{n}$ 16) Introduction, 1-4.

${ }^{125}$ Bogdan, Private International Law as Component of the Law of the Forum (supra n 16) Chapter IX, 206; See Hill and Shuilleabhain (supra $\mathrm{n} 41$ ) 33-42.
} 
is expressly outlawed. For instance, the doctrine of renvoi is excluded in the field of contract by the Rome I Regulation ${ }^{126}$ and in cases of non-contractual obligations by the Rome II Regulation. ${ }^{127}$ Therefore, the issue of the application of renvoi to the applicable law specified by a choice of law agreement does not arise in the first place.

Further limitations on the content of the applicable law specified by a choice of law agreement take the form of overriding mandatory rules and the public policy ${ }^{128}$ (ordre public) of the forum. ${ }^{129}$ The contours of the public policy exception to the applicable law specified by a choice of law agreement can be defined, or at least described, with reference to the role of public policy as a basis for the non-recognition of a judgment under the Brussels I Regulation ${ }^{130}$ as interpreted by the CJEU: ${ }^{131}$

In that regard, the Court explained that recourse to a public policy clause can be envisaged only where recognition or enforcement of the judgment delivered in another Contracting State would be at variance to an unacceptable degree with the legal order of the State in which enforcement is sought inasmuch as it infringes a

\footnotetext{
${ }^{126}$ Article 20 of the Rome I Regulation; See M Altenkirch, "Article 20" in F Ferrari (ed.), Rome I Regulation (Sellier European Law Publishers, 2015) 485-487; Bogdan, Private International Law as Component of the Law of the Forum (supra $\mathrm{n}$ 16) Chapter IX, 210; See also, Article 8 of The Hague Principles on Choice of Law in International Commercial Contracts (supra $\mathrm{n} 14$ ).

${ }^{127}$ Article 24 of Regulation (EC) No 864/2007 of the European Parliament and of the Council on the Law Applicable to Non-Contractual Obligations [2007] OJ L199/40 ("Rome II Regulation"); See M Altenkirch, "Article 24" in P Huber (ed.), Rome II Regulation (Sellier European Law Publishers, 2011) 417-419; Hill and Shuilleabhain (supra $\mathrm{n}$ 41) 34.

${ }^{128}$ For a discussion of a European public policy exception to the rules regarding the enforcement of judgments, see J Fitchen, "Chapter 13 - Article 45" in A Dickinson and E Lein (eds.), The Brussels I Regulation Recast (Oxford University Press, 2015) 432, 440 - 50; Mills, The Confluence (supra n 24) 194 - 98; JK Škerl, "European Public Policy (With an Emphasis on Exequatur Proceedings)"

(2011) 7 Journal of Private International Law 461, 468-74; A Mills, "The Dimensions of Public Policy in Private International Law" (2008) 4 Journal of Private International Law 201, 214 . It is not for the CJEU to define the content of the public policy of the Contracting State but the CJEU has adopted the view that the limits of public policy are a question of interpretation of the Brussels Convention and are therefore a matter which must be determined by it: Case C-7/98 Krombach v Bamberski [2000] ECR I-1935, [22]-[23]; Case C-38/98 Renault v Maxicar [2000] ECR I-2973, [27]-[28]; Case C-394/07 Marco Gambazzi v Daimler Chrysler Canada Inc [2009] ECR I-2563, [26]-[28]; Case C-420/07 Meletis Apostolides v David Charles Orams [2009] ECR I-3571, [56]-[57]; Case C-619/10 Trade Agency Ltd $v$ Seramico Investments Ltd ECLI:EU:C:2012:531, [49]; Case C-302/13 flyLAL-Lithunanian Airlines ECLI:EU:C:2014:2319, [47]; Case C-681/13 Diageo Brands BV v Simiramida ECLI:EU:C:2015:471, [50]. ${ }^{129}$ Bogdan, Private International Law as Component of the Law of the Forum (supra $\mathrm{n}$ 16) Chapter X, 214-257; SC Symeonides, "Party Autonomy in Rome I and II From a Comparative Perspective" in K Boele-Woelki, T Einhorn, D Girsberger and S Symeonides (eds), Convergence and Divergence in Private International Law Liber Amicorum Kurt Siehr (Eleven International Publishing, 2010) 513, 528-530; PJ Borchers, "Categorical Exceptions to Party Autonomy in Private International Law" (2008) 82 Tulane Law Review 1645, 1651-1657; Cf HLE Verhagen, "The Tension between Party Autonomy and European Union Law: Some Observations on Ingmar GB Ltd v Eaton Leonard Technologies Inc" (2002) 51 International and Comparative Law Quarterly 135; See also, Article 11 of The Hague Principles on Choice of Law in International Commercial Contracts (supra $\mathrm{n}$ 14).

${ }^{130}$ Council Regulation (EC) 44/2001 on jurisdiction and the recognition and enforcement of judgments in civil and commercial matters (Brussels I) [2001] OJ L12/1. ("Brussels I Regulation")

${ }^{131}$ Case C-394/07 Marco Gambazzi v Daimler Chrysler Canada Inc [2009] ECR I-2563 [27]; See Case C-7/98 Krombach v Bamberski [2000] ECR I-1935 [37]; Case C-38/98 Renault v Maxicar [2000] ECR I-2973 [30].
} 
fundamental principle. The infringement would have to constitute a manifest breach of a rule of law regarded as essential in the legal order of the State in which enforcement is sought or of a right recognised as being fundamental within that legal order (Krombach, paragraph 37).

Article 9(1) of the Rome I Regulation defines overriding mandatory provisions as: ${ }^{132}$

provisions the respect for which is regarded as crucial by a country for safeguarding its public interests, such as its political, social or economic organization, to such an extent that they are applicable to any situation falling within their scope, irrespective of the law otherwise applicable to the contract under this Regulation.

Apart from the compulsory application of the overriding mandatory provisions of the law of the forum, ${ }^{133}$ effect may be given to such provisions of the law of the country where the obligations arising out of the contract have to be performed. ${ }^{134}$

The mandatory rules and public policy of the forum cannot be derogated from or evaded by a choice of law agreement. ${ }^{135}$ Therefore, the law of the forum retains ultimate control over the content of the applicable law and it is not completely indifferent to the outcome of the dispute. ${ }^{136}$ The overriding mandatory rules of the place of performance of the contract may also limit the scope of the applicable law insofar as those provisions render the performance of the contract unlawful.

Having considered the role of the law of the forum, it is time to examine the viability of remedies for breach of a choice of law agreement within the EU choice of law regime and beyond. Suppose that an international commercial contract is governed by an English choice of law agreement. If a party to the agreement sues in Italy and the Italian courts do not apply the English applicable law by characterizing an issue as procedural or override the applicable law by reference to its mandatory rules and public policy. Can the counterparty sue in England for breach of choice of law agreement? It is submitted, that such a cause of action would doubt the effectiveness of the choice of law regime of the Rome I Regulation. It will also indirectly imply that the party's right to sue in the Italian courts under the

\footnotetext{
${ }^{132}$ A rule with similar effect is found in Article 16 of the Rome II Regulation, although the term "overriding mandatory provisions" is not defined therein.

${ }^{133}$ Article 9(2) of the Rome I Regulation.

${ }^{134}$ Article 9(3) of the Rome I Regulation; See also, Article 7(1) of the Rome Convention; See M Hellner, "Third Country Overriding Mandatory Rules in the Rome I Regulation: Old Wine in New Bottles?" (2009) 5 Journal of Private International Law 447.

135 See Section 27(2) and 27(3) of the Unfair Contract Terms Act 1977 (Geographical Extent: England and Wales, Scotland and Northern Ireland) which apply regardless of the applicable law of the contract where the choice of law agreement appears to the court, or arbitrator to have been imposed wholly or mainly for the purpose of enabling the party imposing it to evade the operation of the Act or in the making of the contract one of the parties dealt as consumer, and he was then habitually resident in the United Kingdom, and the essential steps necessary for the making of the contract were taken there, whether by him or by others on his behalf.

${ }^{136}$ Bogdan, Private International Law as Component of the Law of the Forum (supra n 16) Chapter X, 215.
} 
Brussels la Regulation is undermined. Moreover, it will also mean that there is reason to deny effect to the resulting judgment of the Italian courts. The implications of such a cause of action for the principle of mutual trust and the effectiveness of EU law (effet utile) militate against the possible development of this remedy in the English courts.

To reiterate, it is perhaps misconceived to view the matter from a promissory perspective. The core of good sense in the conventional declaratory function of choice of law agreements has much to recommend it. This is due to the very prominent role of the law of the forum which actually authorises and recognises party autonomy as a connecting factor.

There is, however, one situation in which it has resonance to suggest that non-compliance with a choice of law agreement is a breach of contract. ${ }^{137}$ Suppose that a party commences proceedings in breach of an exclusive choice of court agreement in a court which would not uphold the governing law clause as the agreed court would have done. It would presumably be a breach of contract to advance any argument which denies the effectiveness of the clause. It is submitted, that in practice a court may choose to rely on the more conventional breach of an exclusive jurisdiction agreement to award damages or an anti-suit injunction rather than grounding the action on the novel breach of a choice of law agreement. In the Ace Insurance decision, Brereton J after considering the issue of contravention of the implied negative stipulation arising from a choice of law clause, concluded by awarding an anti-suit injunction for breach of an exclusive jurisdiction agreement in favour of the Australian courts. ${ }^{138}$

\section{Enforcing the Promissory Choice of Law Agreement: Interference with the Principles of Mutual Trust and the Effectiveness of the EU Private International Law Regime}

Prior to considering the enforcement of a breach of a choice of law agreement, it is necessary to examine the particular conception of such agreements in the Rome I Regulation. As observed, the Brussels la Regulation has its own understanding of jurisdiction agreements and Briggs conceives that conception as enshrining a public law notion of jurisdiction, which does not adequately emphasise the contractual rights, encapsulated therein. In similar vein, the key issue is whether the European legislature conceives choice of law clauses in terms of dispute resolution and the conferral of private law rights by virtue of selection of the applicable law. ${ }^{139}$ Arguably, the Rome I Regulation is a complete code for determining which law or laws govern a contract. It seems unlikely that the argument that the choice of law clause has a separate, private law validity (irrespective of the validity

\footnotetext{
${ }^{137}$ Fentiman, International Commercial Litigation (2015) (supra n 1) 129.

${ }^{138}$ Ace Insurance Ltd v. Moose Enterprise Pty Ltd [2009] NSWSC 724, [82]-[83] (Brereton J); See Yeo, Breach of Agreements on Choice of Law (supra n 53) 195; For a discussion of the Ace Insurance decision in the context of the construction of a jurisdiction agreement as exclusive or non-exclusive see R Garnett, "Jurisdiction Clauses Since Akai" [2013] University of Melbourne Law School Research Series 6.

${ }^{139}$ Harris, Agreements on Jurisdiction and Choice of Law: Where Next? (supra $\left.\mathrm{n} 70\right) 553$.
} 
under the Regulation) would appeal to the CJEU. ${ }^{140}$ A subsisting, separate and promissory conception of such agreements would be very difficult to reconcile with a conception of such agreements which focusses on the application of the law of the forum and its choice of law rules which in turn authorise the court to apply the law selected in the choice of law clause, subject to the mandatory rules and public policy of the forum. Therefore, the promissory conception only succeeds in narrating or describing an aspect of the application of the choice of law rules of the forum and may not represent a universally shared understanding of choice of law agreements.

The remedy sought in the Ace Insurance case was an anti-suit injunction to restrain the breach of contract. The cross border injunctive remedy is unavailable to the English courts in respect of proceedings before the courts of another Member State and within the remit of the Brussels la Regulation, as the anti-suit injunction has been deemed to undermine both the principle of effectiveness of the Brussels regime and the overarching mutual trust principle which necessarily animates the EU private international law order. ${ }^{141}$ Similar considerations premised on mutual trust and the principle of the effectiveness of the EU private international law instruments may well preclude cross border injunctive relief to restrain a party from commencing or continuing with proceedings in another Member State for the purpose of avoiding, evading or overriding the applicable law specified in a choice of law agreement. ${ }^{142}$ The primacy of the mutual trust principle may be gleaned from the EU Justice Agenda for 2020 which declares that mutual trust is the "bedrock upon which EU justice policy should be built"143 The controversial remedy remains available in the armoury of the English courts in relation to proceedings outside the European Union. ${ }^{144}$

\footnotetext{
140 Ibid; If an action for breach of the choice of law clause were permitted, this would also raise questions as to which courts should determine the meaning of a choice of law agreement; and whether only the courts first seised in the EU should be empowered to do so. It is submitted, that if there is no jurisdiction agreement accompanying the choice of law clause, the court first seised should proceed to determine the meaning of the choice of law clause.

${ }^{141}$ Case C 159/02 Turner v Grovit [2005] 1 AC 101; Case C 185/07 Allianz SpA v West Tankers Inc [2009] 1 AC 1138.

${ }^{142}$ An argument may be made, however, that the situation is different if the contractual remedy is a matter of application of a law sanctioned by another European Union private international law instrument i.e. the Rome I Regulation. Moreover, the Rome I Regulation does not apply to matters of procedure but if a cause of action for damages for breach of a choice of law agreement impeaches and calls into question the effectiveness of its mandatory private international rules, the Regulation may well preclude the enforcement of subsisting and independent private contractual agreements as to choice of law. It is nevertheless apparently unlikely that the foundational mutual trust principle will lose any of its relevance or significance in relation to the European Union choice of law regime for contractual obligations in civil and commercial matters. For a discussion of the principle of mutual trust as the basis for neutral, multilateral and universal Savignyian conflict of law rules, see, M Weller, "Mutual trust: in search of the future of European Union private international law" (2015) 11 Journal of Private International Law 64, 71-73.

${ }^{143}$ The EU Justice Agenda for 2020 - Strengthening Trust, Mobility and Growth within the Union COM (2014) 144 final; See Weller, Mutual trust (supra $\mathrm{n}$ 142) 79-80.

${ }^{144}$ See Ust-Kamenogorsk Hydropower Plant JSC v AES Ust-Kamenogorsk Hydropower Plant LLP [2013] UKSC 35, [2013] 1 WLR 1889; [2013] 1 CLC 1069 (Lord Mance delivering the judgment of the UK Supreme Court).
} 
As a matter of principle, the award of damages may also be available for breach of a choice of law agreement in accordance with the applicable law of the contract, but this is as yet untested in the case law. ${ }^{145}$ A claim for damages for breach of a choice of law agreement constituted by actions in other Member States may, however, be precluded for being incompatible with the choice of law instruments. ${ }^{146}$ Moreover, the allegation that another Member State court refused or denied effect to the choice of law agreement also imputes that it was somehow wrong for the counterparty to have sued there in the first place. Therefore, both the right to sue in a Member State under the Brussels la Regulation and the application of forum law and choice of law rules under the Rome I Regulation are impeached and called into question. ${ }^{147}$ Furthermore, as the damages remedy has the effect of second guessing and reversing or nullifying the judgment of the courts of another Member State, both the Brussels la Regulation's system of direct rules of jurisdiction and the resulting automatic recognition and enforcement of judgments are undermined. It is submitted that, nullifying or reversing the effect of the foreign judgment is undoubtedly contrary to the principle of mutual trust and the obligation not to question the jurisdiction of another Member State court ${ }^{148}$ and the obligation not to question a Member State court's application of its own choice of law rules. The harmonised rules on jurisdiction and choice of law facilitate the mutual recognition of judgments within the EU and are also animated by the principle of mutual trust. As a general observation, the likelihood for noncompliance with the applicable law in cases where the proceedings are commenced within the Brussels-Lugano regime is remote, because it is unlikely that the application of the same set of choice of law rules ${ }^{149}$ guided by the CJEU's autonomous classifications will result in a breach of contract. ${ }^{150}$

The argument in favour of damages for breach of a choice of law agreement must also overcome the problem that a foreign court's ruling may be res judicata as to the applicable law. Separating the legal functions of a choice of law clause, Briggs suggests that this is not

\footnotetext{
${ }^{145}$ Damages for breach of an English exclusive jurisdiction agreement governed by English law have been awarded by the English courts even against proceedings in the Greek courts and within the remit of the Brussels I Regulation, See, Starlight Shipping Co v Allianz Marine \& Aviation Versicherungs AG (The Alexandros T) [2014] EWCA Civ 1010 (Longmore LJ with whom Rimer L and Lord Toulson agreed); Substantive damages for breach of a jurisdiction agreement have been assumed to be an available remedy under English private international law: Donohue v Armco Inc [2001] UKHL 64, [2002] Lloyd's Rep 425, [2002] CLC 440, [48] (Lord Hobhouse of Woodborough); The Spanish Tribunal Supremo has affirmed the award of substantial damages for breach of a choice of court agreement: Sogo USA Inc v Angel Jesus, STS (Sala de lo Civil, Sección 1a), 12 January 2009, Repertorio de Jurisprudencia 2009/544.

146 Yeo, Breach of Agreements on Choice of Law (supra n 53) 199.

147 Harris, Agreements on Jurisdiction and Choice of Law: Where Next? (supra $\mathrm{n} 70$ ) 554.

${ }^{148}$ Case C-351/89 Overseas Union Insurance Ltd v New Hampshire Insurance Company [1991] ECR I-3317, [23][25]; Case C-116/02 Erich Gasser GmbH v MISAT Srl [2003] ECR I-14693, [48].

${ }^{149}$ There is a greater degree of harmonization in the Rome I Regulation as compared to the Rome Convention; there are no provisions which Member States may reserve against application in the Rome I Regulation. For instance, Germany, Ireland, Luxembourg, Portugal and the United Kingdom entered a reservation under Article 22 of the Rome Convention in relation to Article 7(1) of the Rome Convention. See Bogdan, Private

International Law as Component of the Law of the Forum (supra $\mathrm{n}$ 16) Chapter X, 247.

${ }^{150}$ Yeo, Breach of Agreements on Choice of Law (supra n 53) 200.
} 
incompatible with a finding by the English courts that the parties had a binding promissory agreement as to choice of law. However, if the judgment emanates from a Member State, such an approach comes very near to reviewing the foreign judgment as to its substance, or to second guessing the findings of the foreign court. Even in relation to proceedings brought in non-Member States, the very notion of allowing an action for breach of contract in the English courts seems likely to bring the English courts into conflict with foreign courts that have applied their own choice of law rules. ${ }^{151}$

A claimant will be unable to recover damages in respect of the loss which he has suffered if he cannot establish a causal link between his loss and the defendant's breach of contract or that the loss is too remote. ${ }^{152}$ Suppose that the forum classifies a particular issue as procedural and the chosen law thus does not properly apply to it. If that rule of the procedural law of the forum is the actual cause of the claimant's loss, the chain of causation between the breach of the choice of law agreement and the loss suffered by the claimant will be severed. Similarly, the private international law rules of the forum may have caused the loss sustained by the claimant by regulating the application of the chosen law. Private international law rules are concerned "with the scope of authority of the law, not the outcome in the specific case." ${ }^{153}$ From this perspective, there is no question of breach of the choice of law agreement when the law of the forum applies its choice of law rules. However, if it is determined that there is a breach, it may not always be an easy task to appropriate the entire blame on non-compliance with or breach of the choice of law agreement. The causation issue locates and traces the foundations of the choice of law agreement in the law of the forum and demonstrates the futility of viewing choice of law agreements from a promissory perspective.

The natural extrapolation of Briggs' theoretical speculation is that damages would be available for breach of a choice of law agreement. The theory, no matter howsoever elegant and persuasive gives rise to significant practical difficulty. A major impediment to the

\footnotetext{
${ }^{151}$ A possible solution would be to rely on Section 32 of the Civil Jurisdiction and Judgments Act 1982 which provides that a judgment may arguably not be recognised or enforced in England because it has been obtained in breach of a dispute resolution agreement. The English choice of law agreement would presumably have to be construed as a dispute resolution agreement by the English courts but the language of the provision may not support the claim as its application to choice of law agreements is doubtful; Cf Briggs, Private International Law in English Courts (supra $\mathrm{n} 64$ ) 496; However, if the claimant in the English proceedings had submitted to the jurisdiction of the foreign court, Section 34 of the Civil Jurisdiction and Judgments Act 1982 will bar further proceedings in the English courts.

${ }^{152}$ For a discussion of causation and remoteness in the English and Scots substantive law of contract respectively, see, E McKendrick, Contract Law (Palgrave Macmillan, 2011) 354-360; G Black, Woolman on Contract (W Green, 2010) 145-149; For an analysis of causation and remoteness issues in relation to an action for damages for breach of a choice of forum agreement, see, S Gee, "Lord Bingham, Anti-Suit Injunctions and Arbitration" in M Andenas and D Fairgrieve (eds.), Tom Bingham and the Transformation of the Law: A Liber Amicorum (Oxford University Press, 2009) 635, 641.

${ }^{153}$ Mills, The Confluence (supra $\mathrm{n} 24$ ) 19; Lord Mance describes the higher level secondary norms of private international law as "the infrastructure signposting parties towards the destination to determine substantive issues.": Mance, The Future of Private International Law (supra n 21) 186; See also JG Collier, The Conflict of Laws (Cambridge University Press, 2001) Chapter 1, 6.
} 
rational development of the remedy is the issue of quantification of damages. ${ }^{154}$ Suppose that there is a choice of law agreement for the law of State A. The courts of another state apply the law of State B instead. Should the English courts calculate the loss to the defendant overseas by determining what laws the English courts would have applied, and what the outcome would have been? The English courts applying the Rome I Regulation, may themselves not give unfettered effect to the law of State $A$, and may have imposed upon it mandatory provisions that cannot be derogated from by agreement in English law, or of some other state. The alternative is to consider the result had the law of State A alone been applied, albeit that there may not obviously be any state with jurisdiction which would have applied that law in its entirety and without any reservation. The problem gets enhanced when the court that denied effect to the clause is outside the EU and has fundamentally different choice of law rules as compared to the Rome I Regulation. The root cause of the difficulty stems from a misconception that the law chosen in a choice of law agreement governs each and every aspect of a dispute. However, as observed above, the parties cannot by agreement oust the mandatory choice of law regime of the forum. Characterization of an issue as procedural and outside the proper and legitimate ambit of the lex causae, the application of overriding mandatory provisions of the forum and other states and the public policy of the forum are all outcome determinative and regulate the application of the chosen law. An unfettered, freestanding and truly independent choice of law which applies irrespective of the law of the forum and its choice of law regime does not exist.

Suppose that the original proceedings took place in England and that it was the English courts which were unable to apply the law of State A in its entirety and without any reservation. ${ }^{155}$ Would the English courts applying the choice of law rules of the Rome I Regulation, also have to award monetary compensation for the "loss" caused to the defendant? By bifurcating the legal functions of a choice of law agreement into the law which the parties intended to apply to the contract and the promissory obligation to adhere to the chosen law in a choice of law agreement, it may be possible to allow an action for

\footnotetext{
${ }^{154}$ For the substantial practical difficulties faced by English courts when quantifying damages for breach of a choice of forum agreement, see OT Africa Line Ltd v Magic Sportswear Corp [2005] EWCA Civ 710, [2005] 1 CLC 923, [33] (Longmore LJ): “damages will not be easily calculable and can indeed only be calculated by comparing the advantages and disadvantages of the respective fora. This is likely to involve an even graver a breach of comity than the granting of an anti-suit injunction."; See Briggs, Private International Law in English Courts (supra n 64) 399: "assessment of damages for breach of a jurisdiction clause is liable to be problematic, and any attempt at quantification not much more than speculative"; F Garcimartin, "Chapter 11 - Article 31(2)-(4)" in Dickinson and Lein, Brussels I Regulation Recast (supra n 128) 338; M Illmer, "Chapter 2 - Article 1 " in (ibid) 80: "The calculation of the actual damage will potentially be very difficult and time consuming, carrying a considerable degree of uncertainty."; GB Born, International Commercial Arbitration (Kluwer Law International, $2^{\text {nd }}$ edn, 2014) Chapter 8, 1304: "calculating the quantum of damages is difficult and speculative"; N Blackaby and C Partasides with A Redfern and M Hunter, Redfern and Hunter on International Arbitration (Oxford University Press, $5^{\text {th }}$ edn, 2009) 20: "an agreement to arbitrate is a contract of imperfect obligation. If it is broken, an award of damages is unlikely to be a practical remedy, given the difficulty of quantifying the loss sustained".

${ }^{155}$ Harris, Agreements on Jurisdiction and Choice of Law: Where Next? (supra n 70) 554.
} 
damages for breach of contract in this scenario. ${ }^{156}$ However, it is submitted that the defendant will suffer no loss because the English court has applied the chosen law, subject to the countervailing factors provided for by the Rome I Regulation. It is neither principled nor practicable to separate the procedural and substantive functions of the choice of law agreement because the application of Rome I Regulation's choice of law regime trumps any subsisting, independent and promissory obligation to adhere to the chosen law. Furthermore, a cause of action for damages for breach of a choice of law agreement will negate the impact of the choice of law rules under the Rome I Regulation which makes provision for and limits the scope of party autonomy in the first place.

In addition, one of the reasons for restricting party autonomy in relation to certain types of contracts or fact patterns is because the law seeks to avoid the evasion of the rules of a particular state. In consumer contracts, the consumer retains the protection of rules of his home state, which cannot be derogated from by agreement. ${ }^{157}$ This is a policy which intentionally protects weaker parties and limits party autonomy. However, if the agreement to choose another law can be upheld as a private international law bargain, this protection might come at a price. ${ }^{158} \mathrm{~A}$ business which is sued and subjected to the rules of the consumer's home legal system might obtain damages for that "breach".

\section{Conclusions}

Choice of law considerations are relegated to a secondary position in international civil and commercial litigation before the English courts as compared to international jurisdictional and procedural issues. It has been argued that the emerging transnationalist paradigm of party autonomy supports a conception of choice of law agreements which borrows from both the internationalist and substantive law paradigms of party autonomy but cannot be comprehensively justified by either. This integrated and coherent understanding of choice of law and the law of contract has led to the conclusion that the choice of law clause is a procedural contract but a contract nonetheless.

Briggs' promissory analysis of choice of law agreements is a seminal contribution to legal scholarship. However, it is unlikely that the parallel existence of choice of law agreements as privately enforceable agreements will attract the attention of the CJEU and the European legislature. The common law judicial authority coupled with the preponderance of opposing academic opinion has meant that the conventional "declaratory" classification of choice of law agreements has prevailed over the "promissory" approach. ${ }^{159}$ In assessing the relevance

\footnotetext{
156 Yeo, Breach of Agreements on Choice of Law (supra n 53) 199.

157 Article 6 of the Rome I Regulation; Article 5 of the Rome Convention.

158 Harris, Agreements on Jurisdiction and Choice of Law: Where Next? (supra n 70) 555.

${ }^{159}$ Ace Insurance v Moose Enterprise Pty Ltd [2009] NSWSC 724 (Brereton J); Navig8 Pte Ltd v Al-Riyadh Co for Vegetable Oil Industry (The Lucky Lady) [2013] EWHC 328 (Comm), [2013] 2 Lloyd's Rep 104, [2013] 2 CLC 461 (Andrew Smith J).
} 
and significance of attributing an obligation to adhere to the chosen law in a choice of law agreement, the internationalist paradigm's understanding of the fundamental nature of private international law rules and their inherent function has helped develop the argument.

If the choice of law regime of the forum is conceptualised as a set of secondary rules for the allocation of regulatory authority, the descriptive, normative and interpretive narrative of the promissory perspective loses its perceived dominance and coherence as it fails to yield a complete and satisfactory justification for what we really understand by those rules. In the mantle of secondary power conferring rules as opposed to primary conduct regulating rules, choice of law rules perform a very significant public function of allocating regulatory authority. From this perspective, it is misplaced and misconceived to interpret choice of law clauses as promissory in essence. The promissory justification does not adequately account for the authorization of party autonomy by the choice of law rules of the forum, the supervening application of the laws of the forum and other states and ultimate forum control. Moreover, the pragmatic attractiveness of anti-suit injunctions and claims for damages for breach of choice of law agreements may be unsound in principle from the standpoint of a truly multilateral conception of private international law based on mutual trust or a strong notion of comity. An international private international law will always seek to promote civil judicial cooperation between legal systems rather than encourage the clash of sovereign legal orders by interfering with the jurisdiction, judgments and choice of law apparatus of foreign courts.

To reiterate, the more reconciled transnationalist paradigm of party autonomy strikes a balance between the competing demands of the internationalist and the substantive law paradigms. It has been argued that a conception of a choice of law agreement as a contract, albeit one that does not give rise to any promises inter partes provides an appropriate solution. On the one hand, the choice of law agreement is a bilateral legal act, or a legally binding agreement as opposed to a mere "factual" agreement. On the other hand, the function of this agreement is not to create or modify rights and obligations: it is to opt out of the forum's objective choice of law rules and to choose the applicable law. Such a contract will not contradict the intrinsic logic of choice of law rules because the international allocative function remains paramount and is not compromised in any way by promises inter partes. The fact that the choice of law agreement is a contract which only gives rise to procedural consequences does not mean that it is not, or should not be, described as a contract. 